\title{
A SEQUENTIAL DUAL CLEAVAGE OF THE ARYLSULFAMATE LINKER TO PROVIDE BOTH SULFAMATE AND PHENOL DERIVATIVES
}

\author{
Diane Fournier, Liviu Ciobanu, Donald Poirier*
Laboratory of Medicinal Chemistry, CHU de Québec - Research Center (CHUL, T4), 2705 Laurier Boulevard, Québec (Québec), G1V 4G2, Canada
*e-mail:donald.poirier@crchul.ulaval.ca; phone: 1(418)654-2296; fax: 1(418)654-2298

\begin{abstract}
Tyramine sulfamate was linked to the trityl chloride resin and this polymeric solid support used to introduce two levels of molecular diversity by formation of peptide bonds. A dual cleavage strategy next generated in a sequential way (without resin split) two different types of compounds (phenol and arylsulfamate derivatives), which are therapeutically attractive types of compounds. Here, we used tyramine as a general scaffold, but other arylsulfamate derivatives could be judiciously used to extend the nature of synthesized compounds.
\end{abstract}

Keywords: solid-phase synthesis, linker, sulfamate, phenol, library.

Received: November 2015/ Revised final: November 2015/ Accepted: November 2015

\section{Introduction}

Sulfamate derivatives have been known for several years as artificial sweeteners (cyclamates) [1], but therapeutic applications are numerous and have significantly broadened in recent years $[2,3]$. They were first known as anticonvulsants and the drug topimarate, discovered in 1980, is still used in clinical settings for the treatment of refractory epilepsy [4]. Sulfamate derivatives were also found to be potent inhibitors of carbonic anhydrases (CAs) $[5,6]$. This could explain the high oral availability of these drugs since they were shown to bind reversibly to CA II in red blood cells, which allows them to avoid degradation in the liver. This property could lead to new therapeutic approaches against cancer because CA IX and CA XII are highly expressed in tumours which need them to maintain pH and eliminate $\mathrm{CO}_{2}$. Arylsulfamates have shown high potency as inhibitors of steroid sulfatase (STS) [7-10], an important therapeutic target for the treatment of hormone-sensitive diseases such as breast, endometrium and prostate cancers [11,12] in addition to acne and alopecia [13]. STS inhibitors could also have potential in the treatment of Alzheimer's disease through an increase in the level of dehydroepiandrosteronesulfate, a substrate of STS in the brain [14].

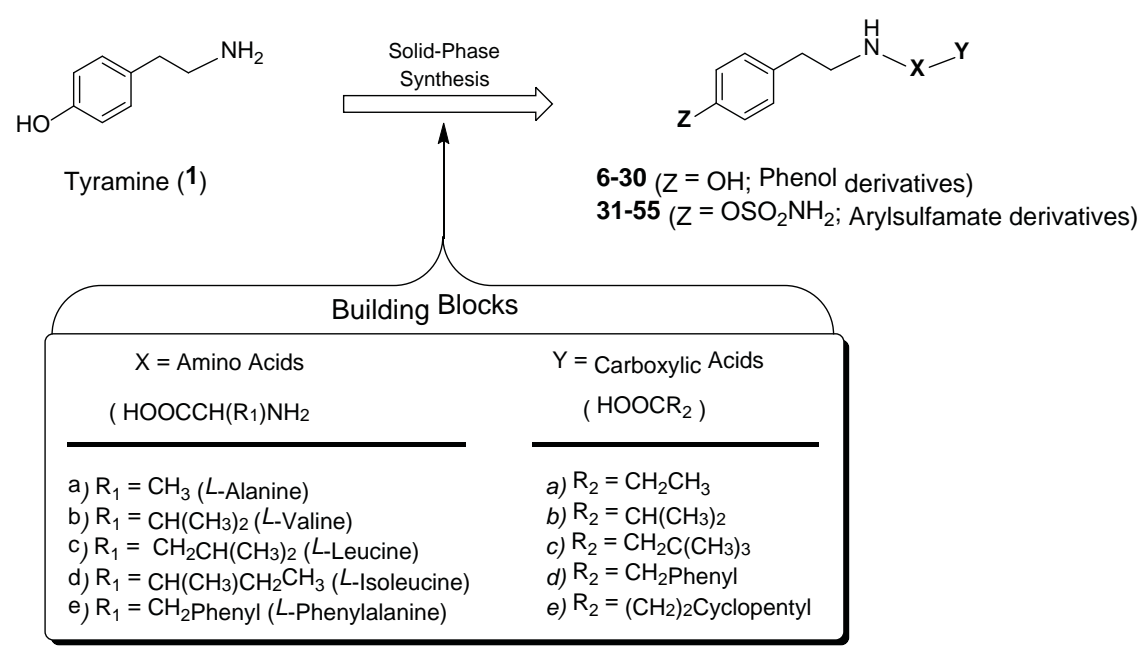

Figure 1. Building blocks (amino acids and carboxylic acids) used in the elaboration of libraries of diversified phenol derivatives 6-30 and arylsulfamate derivatives 31-55.

On the other hand, phenol derivatives are present in many biologically active molecules. For example, many natural antioxidants, such as flavonoids and polyphenols, contain the phenol moiety. These compounds are known to exert a protective effect on cardiovascular health through the lowering of low-density lipoproteins. Many similar compounds were synthesized with the hope of optimizing such properties [15]. Phenols are also very abundant in essential oils, contributing to their aroma and antimicrobial properties [16]. Small phenolic molecules have shown potential as analgesics [17] and

Presented at the XVIII-th International Conference "Physical Methods in Coordination and Supramolecular Chemistry"

(Dedicated to the memory of the professor Constantin Turta and professor Mihail Revenco), 8-9 October 2015, Chisinau, Republic of Moldova 
some have been tested as non-steroidal anti-inflammatory drugs [18] for their potential anti-rejection properties. Moreover, the phenolic group is essential in selective-estrogen receptor modulator drugs [19], which are used in the treatment of hormone-sensitive breast cancer and osteoporosis. Phenol derivatives are also known as inhibitors of $17 \beta$-hydroxysteroid dehydrogenases [20-22] and reversible inhibitors of STS [23,24] (although less potent than sulfamate derivatives).

The ability to generate libraries of phenol and arylsulfamate derivatives from the same resins, through rapid parallel synthesis, is thus of high interest for medicinal chemists. Herein, we describe a strategy (Figures 1 and 2) to generate two different kinds of compounds (sulfamate and phenol derivatives) from commercially available building blocks (amino acids and carboxylic acids) and the multidetachablesulfamate linker [25].

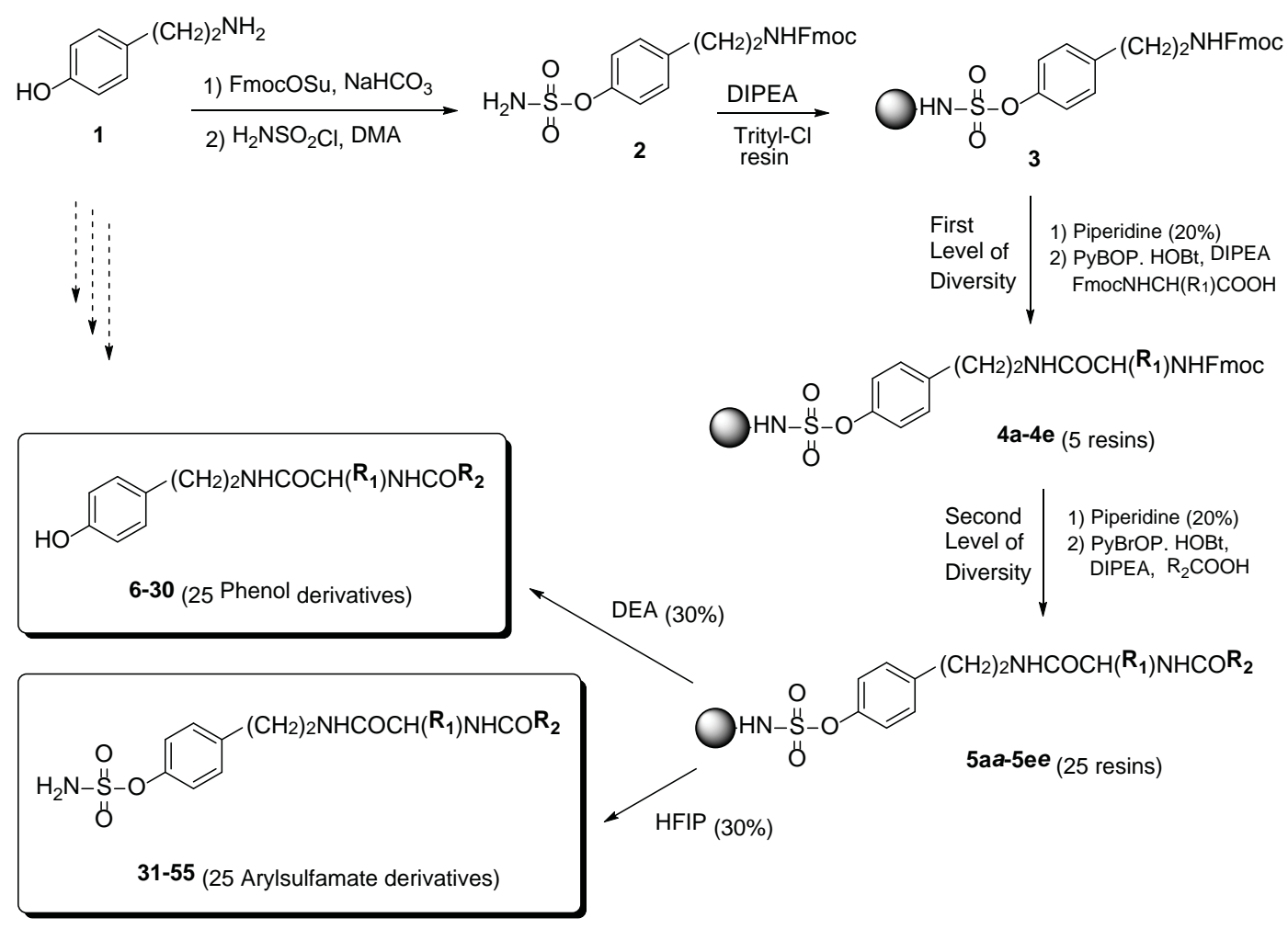

Figure 2. Solid-phase chemical synthesis of libraries of phenol and arylsulfamate derivatives using the sequential approach of cleavage. See Figure 1, Table 1 and Table 2 for the building blocks used in the preparation of libraries and the representation of all library members.

\section{Results and discussion \\ Synthesis of libraries}

The solid-phase strategy providing two types of diversified molecules, the phenol and sulfamate derivatives, was represented in Figure 2. The primary amine of tyramine (1) was first protected as a 9-fluorenylmethoxycarbonyl (Fmoc) derivative, whereas the phenol group was next transformed by the sulfamoyl chloride in N,N-dimethyacetamide (DMA) used as base and solvent [26] to provide 2. This arylsulfamate was linked to a polystyrene solid support by a reaction with trityl chloride resin in presence of diisopropylethylamine (DIPEA), thus providing the resin 3 . The mass increase suggested a quantitative yield for the coupling reaction. The characteristic band of Fmoc $\left(1696 \mathrm{~cm}^{-1}\right)$ and sulfamoyl $\left(1350\right.$ and $\left.1156 \mathrm{~cm}^{-1}\right)$ groups were observed in FTIR spectra. A gel-phase ${ }^{13} \mathrm{C}$ NMR analysis of resin 3 showed all carbon signals associated with tyramine moiety. Finally, a micro-cleavage under acid conditions released the sulfamate 2 . All these results confirmed the presence of a tyramine residue linked on the trityl resin and consequently the formation of 3 , the precursor of all library members.

The synthesis of libraries started by removing the Fmoc protecting group of $\mathbf{3}$ to generate the corresponding free primary amine, which was submitted to a coupling reaction using benzotriazol-1-yl-oxy-tris-pyrrolidino-phosphonium hexafluorophosphate (PyBOP), 1-hydroxybenzotriazole (HOBt) and an amino acid. A series of five amino acids (Figure 1) protected as N-Fmoc derivative was the key element used to introduce the first level of molecular diversity. The formation of resins 4a-4e was supported by the presence in FTIR spectra of a new amide $(\mathrm{NC}=\mathrm{O})$ band in the range of 1656-1660 $\mathrm{cm}^{-1}$. To introduce the second level of diversity, the five resins 4a-4e were split in 5 groups ( 25 samples) and submitted to a sequence of two steps, the cleavage of Fmoc group and the coupling of five carboxylic acids using PyBrOP and HOBt, thus producing resins 5aa-5ee. 


\section{Cleavage strategy (recovering the final compounds)}

The sequential dual cleavage consisted in performing, on the same resin sample, first a partial release of a phenol derivative with a nucleophile, and next a cleavage of the remaining linked material with an acid to obtain an arylsulfamate derivative. This approach avoids the step of splitting the resin, which is time-consuming.

The type of cleavage we call «nucleophilic» here is not strictly speaking nucleophilic, but this type of reaction was studied in detail by Spillane et al. [27-30]. The mechanism is a two-step base-catalysed E1cb-type mechanism that probably involves a bimolecular complex between a base and the sulfamate $\mathrm{NH}$ as intermediate, which is then attacked by a nucleophile to release the phenol. In this case, we carried out an incomplete nucleophilic cleavage at room temperature with $30 \%$ of diethylamine (DEA), which released about $50 \%$ of the linked material as the phenol derivatives 6-30 (Table 1).

Table 1

Representation of all library members (phenol derivatives 6-30).

\begin{tabular}{|c|c|c|c|c|c|}
\hline \multirow[t]{2}{*}{$\begin{array}{c}\text { General } \\
\text { structure }\end{array}$} & & & & & \\
\hline & $\begin{array}{l}\mathrm{CH}_{2} \mathrm{CH}_{3} \\
\text { (Propionic Acid) } \\
a\end{array}$ & $\begin{array}{l}\mathbf{C H}\left(\mathbf{C H}_{3}\right)_{2} \\
(i-B u t y r i c \text { Acid }) \\
b\end{array}$ & $\begin{array}{l}\mathbf{C H}_{2} \mathbf{C}\left(\mathbf{C H}_{3}\right)_{3} \\
\text { (t-Butylacetic } \\
\text { Acid) } \\
c\end{array}$ & $\begin{array}{l}\mathbf{C H}_{2} \text {-Phenyl } \\
\text { (Phenylacetic } \\
\text { Acid) } \\
d\end{array}$ & $\begin{array}{l}\left(\mathrm{CH}_{2}\right)_{2}^{-} \\
\text {Cyclopentyl } \\
\text { (3-Cyclopentyl- } \\
\text { propionic Acid) } \\
e\end{array}$ \\
\hline $\begin{array}{l}\mathbf{C H}_{3} \\
\text { (Alanine) } \\
\mathrm{a}\end{array}$ & $\begin{array}{l}\# \mathbf{6} \\
\mathrm{C}_{14} \mathrm{H}_{22} \mathrm{~N}_{2} \mathrm{O}_{3} \\
\mathrm{~W}: 8.9 \mathrm{mg} \\
\text { CY: } 59 \% \\
\text { P: } 48 \%\end{array}$ & $\begin{array}{l}\# 7 \\
\mathrm{C}_{15} \mathrm{H}_{22} \mathrm{~N}_{2} \mathrm{O}_{3} \\
\mathrm{~W}: 9.0 \mathrm{mg} \\
\mathrm{CY}: 56 \%\end{array}$ & $\begin{array}{l}\# \mathbf{8} \\
\mathrm{C}_{17} \mathrm{H}_{26} \mathrm{~N}_{2} \mathrm{O}_{3} \\
\mathrm{~W}: 16.7 \mathrm{mg} \\
\mathrm{CY}: 98 \%\end{array}$ & $\begin{array}{l}\# \mathbf{9} \\
\mathrm{C}_{19} \mathrm{H}_{22} \mathrm{~N}_{2} \mathrm{O}_{3} \\
\mathrm{~W}: 12.2 \mathrm{mg} \\
\mathrm{CY}: 64 \%\end{array}$ & $\begin{array}{l}\# \mathbf{1 0} \\
\mathrm{C}_{19} \mathrm{H}_{28} \mathrm{~N}_{2} \mathrm{O}_{3} \\
\mathrm{~W}: 10.4 \mathrm{mg} \\
\mathrm{CY}: 55 \% \\
\mathrm{P}: 60 \%\end{array}$ \\
\hline $\begin{array}{l}\mathrm{CH}\left(\mathrm{CH}_{3}\right)_{2} \\
\text { (Valine) } \\
\text { b }\end{array}$ & $\begin{array}{l}\# 11 \\
\mathrm{C}_{16} \mathrm{H}_{24} \mathrm{~N}_{2} \mathrm{O}_{3} \\
\mathrm{~W}: 10.5 \mathrm{mg} \\
\text { CY: } 62 \%\end{array}$ & $\begin{array}{l}\# \mathbf{1 2} \\
\mathrm{C}_{17} \mathrm{H}_{26} \mathrm{~N}_{2} \mathrm{O}_{3} \\
\text { W: } 9.7 \mathrm{mg} \\
\text { CY: } 57 \% \\
\text { P: } 82 \%\end{array}$ & $\begin{array}{l}\# \mathbf{1 3} \\
\mathrm{C}_{19} \mathrm{H}_{30} \mathrm{~N}_{2} \mathrm{O}_{3} \\
\mathrm{~W}: 18.4 \mathrm{mg} \\
\mathrm{CY}: 97 \%\end{array}$ & $\begin{array}{l}\mathbf{1 4} \\
\mathrm{C}_{21} \mathrm{H}_{26} \mathrm{~N}_{2} \mathrm{O}_{3} \\
\mathrm{~W}: 12.9 \mathrm{mg} \\
\mathrm{CY}: 64 \%\end{array}$ & $\begin{array}{l}\# \mathbf{1 5} \\
\mathrm{C}_{21} \mathrm{H}_{32} \mathrm{~N}_{2} \mathrm{O}_{3} \\
\mathrm{~W}: 10.9 \mathrm{mg} \\
\mathrm{CY}: 55 \% \\
\mathrm{P}: 81 \%\end{array}$ \\
\hline $\begin{array}{l}\mathrm{CH}_{2} \mathrm{CH}\left(\mathrm{CH}_{3}\right)_{2} \\
\text { (Leucine) } \\
\text { c }\end{array}$ & $\begin{array}{l}\# \mathbf{1 6} \\
\mathrm{C}_{17} \mathrm{H}_{22} \mathrm{~N}_{2} \mathrm{O}_{3} \\
\mathrm{~W}: 11.9 \mathrm{mg} \\
\text { CY: } 70 \% \\
\text { P: } 39 \% \\
\end{array}$ & $\begin{array}{l}\# \mathbf{1 7} \\
\mathrm{C}_{18} \mathrm{H}_{28} \mathrm{~N}_{2} \mathrm{O}_{3} \\
\mathrm{~W}: 14.8 \mathrm{mg} \\
\mathrm{CY}: 82 \%\end{array}$ & $\begin{array}{l}\text { \# 18 } \\
\mathrm{C}_{20} \mathrm{H}_{32} \mathrm{~N}_{2} \mathrm{O}_{3} \\
\mathrm{~W}: 15.9 \mathrm{mg} \\
\text { CY: } 80 \% \\
\text { P: } 47 \% \\
\end{array}$ & $\begin{array}{l}\# \mathbf{1 9} \\
\mathrm{C}_{22} \mathrm{H}_{28} \mathrm{~N}_{2} \mathrm{O}_{3} \\
\mathrm{~W}: 15.5 \mathrm{mg} \\
\text { CY: } 74 \%\end{array}$ & $\begin{array}{l}\mathbf{2 0} \\
\mathrm{C}_{22} \mathrm{H}_{34} \mathrm{~N}_{2} \mathrm{O}_{3} \\
\mathrm{~W}: 13.1 \mathrm{mg} \\
\mathrm{CY}: 77 \%\end{array}$ \\
\hline $\begin{array}{l}\mathrm{CH}\left(\mathrm{CH}_{3}\right) \mathrm{CH}_{2} \mathrm{CH}_{3} \\
\text { (Isoleucine) } \\
\text { d }\end{array}$ & $\begin{array}{l}\# 21 \\
\mathrm{C}_{17} \mathrm{H}_{22} \mathrm{~N}_{2} \mathrm{O}_{3} \\
\mathrm{~W}: 8.7 \mathrm{mg} \\
\text { CY: } 51 \%\end{array}$ & $\begin{array}{l}\# \mathbf{2 2} \\
\mathrm{C}_{18} \mathrm{H}_{28} \mathrm{~N}_{2} \mathrm{O}_{3} \\
\mathrm{~W}: 10.2 \mathrm{mg} \\
\text { CY: } 57 \% \\
\text { P: } 79 \%\end{array}$ & $\begin{array}{l}\# 23 \\
\mathrm{C}_{20} \mathrm{H}_{32} \mathrm{~N}_{2} \mathrm{O}_{3} \\
\mathrm{~W}: 19.3 \mathrm{mg} \\
\mathrm{CY}: 96 \%\end{array}$ & \begin{tabular}{|l|}
$\# \mathbf{2 4}$ \\
$\mathrm{C}_{22} \mathrm{H}_{28} \mathrm{~N}_{2} \mathrm{O}_{3}$ \\
$\mathrm{~W}: 17.5 \mathrm{mg}$ \\
$\mathrm{CY}: 83 \%$ \\
P: $48 \%$ \\
\end{tabular} & $\begin{array}{l}\mathbf{2 5} \\
\mathrm{C}_{22} \mathrm{H}_{34} \mathrm{~N}_{2} \mathrm{O}_{3} \\
\mathrm{~W}: 10.9 \mathrm{mg} \\
\mathrm{CY}: 52 \%\end{array}$ \\
\hline $\begin{array}{l}\mathbf{C H}_{2}-\text { Phenyl } \\
\text { (Phenylalanine) } \\
\mathrm{e}\end{array}$ & $\begin{array}{l}\# \mathbf{2 6} \\
\mathrm{C}_{20} \mathrm{H}_{24} \mathrm{~N}_{2} \mathrm{O}_{3} \\
\mathrm{~W}: 14.4 \mathrm{mg} \\
\text { CY: } 76 \%\end{array}$ & $\begin{array}{l}\# 27 \\
\mathrm{C}_{21} \mathrm{H}_{26} \mathrm{~N}_{2} \mathrm{O}_{3} \\
\mathrm{~W}: 16.7 \mathrm{mg} \\
\mathrm{CY}: 84 \%\end{array}$ & $\begin{array}{l}\mathbf{2 8} \\
\mathrm{C}_{23} \mathrm{H}_{30} \mathrm{~N}_{2} \mathrm{O}_{3} \\
\mathrm{~W}: 19.7 \mathrm{mg} \\
\text { CY: } 90 \% \\
\text { P: } 52 \%\end{array}$ & $\begin{array}{l}\text { \# 29 } \\
\mathrm{C}_{25} \mathrm{H}_{26} \mathrm{~N}_{2} \mathrm{O}_{3} \\
\mathrm{~W}: 15.9 \mathrm{mg} \\
\mathrm{CY}: 69 \% \\
\text { P: } 68 \%\end{array}$ & $\begin{array}{l}\text { \# 30 } \\
\mathrm{C}_{25} \mathrm{H}_{32} \mathrm{~N}_{2} \mathrm{O}_{3} \\
\text { W: } 14.4 \mathrm{mg} \\
\text { CY: } 63 \%\end{array}$ \\
\hline
\end{tabular}

W: Weight of released compound; CY: crude yield; $P$ : purity determined by quantitative ${ }^{1} \mathrm{H} N M R$.

$(*) R_{1}$ : The residue of amino acids used as building blocks.

(**) $R_{2}$ : The residue of carboxylic acids used as building blocks.

The acidic cleavage probably proceeds through protonation of the sulfamate $\mathrm{NH}$ and subsequent formation of a trityl anion on the resin (which takes on an intense red color). In the first assays, the acidic cleavage used to produce the arylsulfamate derivative was done using a 5\% trifluoroacetic acid (TFA) solution in $\mathrm{CH}_{2} \mathrm{Cl}_{2}$, which gave better yields with shorter reaction times, but lower purity. Since we intended our solid-phase synthesis products for screening purposes, and thus wanted rapid production with no purification step, milder acid conditions (30\% hexafluoroisopropanol (HFIP) in $\mathrm{CH}_{2} \mathrm{Cl}_{2}$ ) were preferred to generate the arylsulfamate derivatives 31-55 (Table 2).

After we generated two libraries of phenol derivatives (Table 1) and arylsulfamate derivatives (Table 2), all the library members were analysed by thin-layer chromatography and showed a good homogeneity (mostly one spot). A sampling of both libraries (10 members by library) was performed and the compounds tested by NMR analysis. We chose quantitative NMR over HPLC for purity assessment because it allows the detection of the real quantity of the 
desired product in a given mass even if an impurity is insoluble or invisible to NMR. On the contrary, since purity assessment with HPLC depends on what is visible to the detector, insoluble or detector-invisible material is not taken into account, and thus artificially high purity values are read.

It should be noted that no purification steps whatsoever are used in the procedure described above. Nonetheless, we think the average purity of the products (phenol derivatives: 39 to $82 \%$, average $60 \%$; arylsulfamate derivatives: 38 to $66 \%$, average $53 \%$ ) could be increased by optimizing the coupling steps. Moreover, we noticed that some resins developed a red-brownish color after an amino-acid coupling cycle, and this color could not be washed away. After cleavage, the products showed low purity. Impurities were sometimes visible on ${ }^{1} \mathrm{H}$ NMR spectra as direct capping (resulting from incomplete amino-acid coupling) or phosphorus derivatives (from PyBOP and PyBrOP coupling agents). These results do not seem to be systematic since different amino acids are affected in different trials. They were not observed in two compounds previously generated as models, as in those cases average purity of the crude product was $80 \%$ and excellent purity and yields were obtained after chromatography. The lower purities could have many causes. For example, it is known that PyBOP and PyBrOP produce deleterious esters when left in solution in DMF for long periods (more than one hour). These esters probably form a large part of the impurities and could be avoided by shortening coupling cycles (one hour each), by choosing other coupling reagents, or by using DMA instead of DMF (PyBOP and PyBrOP are stable for several days in DMA). The low purity could also result from cross-contamination when using the synthesizer, which was not used in the preparation of the two model compounds. However, products with higher purity could be obtained by performing a silica gel filtration or a flash chromatography [31]. Libraries of steroidal sulfamates have also been successfully generated in high yields and purities [31-33].

Table 2

Representation of all library members (arylsulfamate derivatives 31-55).

\begin{tabular}{|c|c|c|c|c|c|}
\hline $\begin{array}{c}\text { General } \\
\text { structure }\end{array}$ & & & $\mathrm{H}$ & & \\
\hline $\mathrm{R}_{2}{ }^{* *}$ & $\begin{array}{l}\mathrm{CH}_{2} \mathrm{CH}_{3} \\
\text { (Propionic Acid) } \\
a\end{array}$ & $\begin{array}{l}\mathbf{C H}\left(\mathrm{CH}_{3}\right)_{2} \\
(i-\text { Butyric Acid }) \\
b\end{array}$ & \begin{tabular}{|l|}
$\mathbf{C H}_{2} \mathbf{C}\left(\mathrm{CH}_{3}\right)_{3}$ \\
( $t$-Butylac etic \\
Acid) \\
$c$
\end{tabular} & $\begin{array}{l}\mathrm{CH}_{2} \text {-Phenyl } \\
\text { (Phenylac e tic } \\
\text { Acid) } \\
d\end{array}$ & $\begin{array}{l}\left(\mathrm{CH}_{2}\right)_{2^{-}} \\
\text {Cyclopentyl } \\
\text { (3-Cyclopentyl- } \\
\text { propionic Acid) } \\
e\end{array}$ \\
\hline $\begin{array}{l}\mathrm{CH}_{3} \\
\text { (Alanine) } \\
\mathrm{a}\end{array}$ & $\begin{array}{l}\# \mathbf{3 1} \\
\mathrm{C}_{14} \mathrm{H}_{21} \mathrm{~N}_{3} \mathrm{O}_{5} \mathrm{~S} \\
\mathrm{~W}: 15.5 \mathrm{mg} \\
\mathrm{CY}: 78 \% \\
\text { P: } 52 \%\end{array}$ & $\begin{array}{l}\# 32 \\
\mathrm{C}_{15} \mathrm{H}_{23} \mathrm{~N}_{3} \mathrm{O}_{5} \mathrm{~S} \\
\text { W: } 10.5 \mathrm{mg} \\
\mathrm{CY}: 52 \%\end{array}$ & $\begin{array}{l}\# 33 \\
\mathrm{C}_{17} \mathrm{H}_{27} \mathrm{~N}_{3} \mathrm{O}_{5} \mathrm{~S} \\
\text { W: } 15.2 \mathrm{mg} \\
\text { CY: } 69 \%\end{array}$ & $\begin{array}{l}\# 34 \\
\mathrm{C}_{19} \mathrm{H}_{23} \mathrm{~N}_{3} \mathrm{O}_{5} \mathrm{~S} \\
\mathrm{~W}: 16.1 \mathrm{mg} \\
\mathrm{CY}: 70 \%\end{array}$ & $\begin{array}{l}\# 35 \\
\mathrm{C}_{19} \mathrm{H}_{29} \mathrm{~N}_{3} \mathrm{O}_{5} \mathrm{~S} \\
\mathrm{~W}: 13.5 \mathrm{mg} \\
\mathrm{CY}: 59 \% \\
\text { P: } 48 \%\end{array}$ \\
\hline $\begin{array}{l}\mathrm{CH}\left(\mathrm{CH}_{3}\right)_{2} \\
\text { (Valine) } \\
\text { b }\end{array}$ & $\begin{array}{l}\# 36 \\
\mathrm{C}_{16} \mathrm{H}_{25} \mathrm{~N}_{3} \mathrm{O}_{5} \mathrm{~S} \\
\mathrm{~W}: 10.3 \mathrm{mg} \\
\mathrm{CY}: 49 \%\end{array}$ & $\begin{array}{l}\# \mathbf{3 7} \\
\mathrm{C}_{17} \mathrm{H}_{27} \mathrm{~N}_{3} \mathrm{O}_{5} \mathrm{~S} \\
\text { W: } 13.0 \mathrm{mg} \\
\mathrm{CY}: 59 \% \\
\text { P: } 46 \% \\
\end{array}$ & $\begin{array}{l}\# \mathbf{3 8} \\
\mathrm{C}_{19} \mathrm{H}_{31} \mathrm{~N}_{3} \mathrm{O}_{5} \mathrm{~S} \\
\mathrm{~W}: 13.7 \mathrm{mg} \\
\mathrm{CY}: 57 \%\end{array}$ & $\begin{array}{l}39 \\
\mathrm{C}_{21} \mathrm{H}_{27} \mathrm{~N}_{3} \mathrm{O}_{5} \mathrm{~S} \\
\mathrm{W:} 15.7 \mathrm{mg} \\
\text { CY: } 63 \%\end{array}$ & $\begin{array}{l}\# \mathbf{4 0} \\
\mathrm{C}_{21} \mathrm{H}_{33} \mathrm{~N}_{3} \mathrm{O}_{5} \mathrm{~S} \\
\text { W: } 12.2 \mathrm{mg} \\
\text { CY: } 49 \% \\
\text { P: } 38 \%\end{array}$ \\
\hline $\begin{array}{l}\mathrm{CH}_{2} \mathbf{C H}\left(\mathrm{CH}_{3}\right)_{2} \\
\text { (Leucine) } \\
\text { c }\end{array}$ & $\begin{array}{l}\text { \# } \mathbf{4 1} \\
\mathrm{C}_{17} \mathrm{H}_{27} \mathrm{~N}_{3} \mathrm{O}_{5} \mathrm{~S} \\
\mathrm{~W}: 16.2 \mathrm{mg} \\
\mathrm{CY}: 74 \% \\
\mathrm{P}: 66 \% \\
\end{array}$ & $\begin{array}{l}\# 42 \\
\mathrm{C}_{18} \mathrm{H}_{29} \mathrm{~N}_{3} \mathrm{O}_{5} \mathrm{~S} \\
\text { W: } 16.6 \mathrm{mg} \\
\mathrm{CY}: 72 \%\end{array}$ & \begin{tabular}{|l}
$\# \mathbf{4 3}$ \\
$\mathrm{C}_{20} \mathrm{H}_{33} \mathrm{~N}_{3} \mathrm{O}_{5} \mathrm{~S}$ \\
W: $16.1 \mathrm{mg}$ \\
$\mathrm{CY}: 67 \%$ \\
P: $53 \%$ \\
\end{tabular} & $\begin{array}{l}\# \mathbf{4 4} \\
\mathrm{C}_{22} \mathrm{H}_{29} \mathrm{~N}_{3} \mathrm{O}_{5} \mathrm{~S} \\
\mathrm{~W}: 16.9 \mathrm{mg} \\
\mathrm{CY}: 65 \%\end{array}$ & $\begin{array}{l}\# \mathbf{4 5} \\
\mathrm{C}_{22} \mathrm{H}_{35} \mathrm{~N}_{3} \mathrm{O}_{5} \mathrm{~S} \\
\text { W: } 14.8 \mathrm{mg} \\
\mathrm{CY}: 57 \%\end{array}$ \\
\hline $\begin{array}{l}\mathrm{CH}\left(\mathrm{CH}_{3}\right) \\
\mathrm{CH}_{2} \mathrm{CH}_{3} \\
\text { (Isoleucine) } \\
\text { d }\end{array}$ & $\begin{array}{l}\# \mathbf{4 6} \\
\mathrm{C}_{17} \mathrm{H}_{27} \mathrm{~N}_{3} \mathrm{O}_{5} \mathrm{~S} \\
\mathrm{~W}: 11.1 \mathrm{mg} \\
\text { CY: } 50 \%\end{array}$ & $\begin{array}{l}\# \mathbf{4 7} \\
\mathrm{C}_{18} \mathrm{H}_{29} \mathrm{~N}_{3} \mathrm{O}_{5} \mathrm{~S} \\
\text { W: } 11.7 \mathrm{mg} \\
\text { CY: } 51 \% \\
\text { P: } 65 \%\end{array}$ & $\begin{array}{l}\# \mathbf{4 8} \\
\mathrm{C}_{20} \mathrm{H}_{33} \mathrm{~N}_{3} \mathrm{O}_{5} \mathrm{~S} \\
\mathrm{~W}: 14.1 \mathrm{mg} \\
\mathrm{CY}: 59 \%\end{array}$ & $\begin{array}{l}\# \mathbf{4 9} \\
\mathrm{C}_{22} \mathrm{H}_{29} \mathrm{~N}_{3} \mathrm{O}_{5} \mathrm{~S} \\
\mathrm{~W}: 13.8 \mathrm{mg} \\
\mathrm{CY}: 53 \% \\
\mathrm{P}: 54 \%\end{array}$ & $\begin{array}{l}\# \mathbf{5 0} \\
\mathrm{C}_{22} \mathrm{H}_{35} \mathrm{~N}_{3} \mathrm{O}_{5} \mathrm{~S} \\
\mathrm{~W}: 12.2 \mathrm{mg} \\
\mathrm{CY}: 47 \%\end{array}$ \\
\hline $\begin{array}{l}\mathbf{C H}_{2}-\text { Phenyl } \\
\text { (Phenylalanine) } \\
\mathrm{e}\end{array}$ & $\begin{array}{l}\# \mathbf{5 1} \\
\mathrm{C}_{20} \mathrm{H}_{25} \mathrm{~N}_{3} \mathrm{O}_{5} \mathrm{~S} \\
\text { W: } 14.5 \mathrm{mg} \\
\text { CY: } 60 \%\end{array}$ & $\begin{array}{l}\# \mathbf{5 2} \\
\mathrm{C}_{21} \mathrm{H}_{27} \mathrm{~N}_{3} \mathrm{O}_{5} \mathrm{~S} \\
\mathrm{~W}: 15.8 \mathrm{mg} \\
\mathrm{CY}: 63 \%\end{array}$ & $\begin{array}{l}\# \mathbf{5 3} \\
\mathrm{C}_{23} \mathrm{H}_{31} \mathrm{~N}_{3} \mathrm{O}_{5} \mathrm{~S} \\
\mathrm{~W}: 14.8 \mathrm{mg} \\
\mathrm{CY}: 57 \% \\
\text { P: } 50 \% \\
\end{array}$ & $\begin{array}{l}\# \mathbf{5 4} \\
\mathrm{C}_{25} \mathrm{H}_{27} \mathrm{~N}_{3} \mathrm{O}_{5} \mathrm{~S} \\
\mathrm{~W}: 16.2 \mathrm{mg} \\
\mathrm{CY}: 60 \% \\
\mathrm{P}: 57 \%\end{array}$ & $\begin{array}{l}\# \mathbf{5 5} \\
\mathrm{C}_{22} \mathrm{H}_{33} \mathrm{~N}_{3} \mathrm{O}_{5} \mathrm{~S} \\
\mathrm{~W}: 13.7 \mathrm{mg} \\
\mathrm{CY}: 49 \%\end{array}$ \\
\hline
\end{tabular}

W: Weight of released compound; $C Y$ : crude yield; $P$ : purity determined by quantitative ${ }^{1} H$ NMR.

$\left({ }^{*}\right) R_{1}$ : The residue of amino acids used as building blocks.

(**) $R_{2}$ : The residue of carboxylic acids used as building blocks. 


\section{Conclusions}

The multidetachablesulfamate linker used herein allowed the preparation of both phenol and arylsulfamate derivatives, which are therapeutically attractive types of compounds. The loading step on trityl chloride resin is quantitative and the peptide coupling reactions are compatible with this linker. The dual cleavage strategy allowed us to generate two different types of compounds in a sequential way (without resin split). Here, we used the Fmoctyramine sulfamate (2) as a general scaffold to introduce two levels of diversification, but other arylsulfamates could be judiciously used to extend the nature of the synthesized compounds. The sulfamate linker thus represents a valuable addition to the chemical tools available to the medicinal and organic chemists.

\section{Experimental \\ General remarks}

9-Fluorenylmethyl succinimidyl carbonate (FmocOSu) and Fmoc-protected amino-acids were purchased from Advanced ChemTech, (Louisville, KY, USA). PyBOP, PyBrOP, anhydrous DMF and trityl resin were purchased from Novabiochem (EMD Biosciences, San Diego, CA, USA). Other reagents were purchased from Aldrich (Milwaukee, WI, USA). The sulfamoyl chloride (moisture sensitive) was prepared from chlorosulfonyl isocyanate and concentrated $\mathrm{HCl}$ according to a known procedure [34]. All reagents were used as provided. A Jouan RC1010 SpeedVac apparatus (Winchester, VA, USA) was used for the solvent evaporation of the final library compounds. FTIR spectra were obtained on a Perkin-Elmer 1600 spectrophotometer (Norwalk, CT, USA). ${ }^{13} \mathrm{C}$ NMR spectra were recorded at $75.5 \mathrm{MHz}$ on a Bruker AC/F 300 spectrometer (Billerica, MA, USA). ${ }^{1} \mathrm{H}$ NMR spectra with and without internal reference were recorded at $400 \mathrm{MHz}$ on a Bruker Avance 400 Spectrometer (Billerica, MA, USA). The NMR purity of the cleaved products was determined using the external reference method. The reference compound (1,2,4-triazole) was dissolved in DMSO-d $\mathrm{d}_{6}$ and placed in a WGS-5BL coaxial insert (WILMAD, Buena, NJ, USA).

\section{Synthesis of sulfamate derivative 2}

To a stirred solution of tyramine (1) $(1.80 \mathrm{~g}, 13.12 \mathrm{mmol})$ in $\mathrm{THF} / \mathrm{H}_{2} \mathrm{O}(3: 1, \mathrm{v} / \mathrm{v})(225 \mathrm{~mL})$ were added, successively, aqueous $1.0 \mathrm{~N} \mathrm{NaHCO}_{3}(27 \mathrm{~mL})$ and FmocOSu $(4.47 \mathrm{~g}, 13.25 \mathrm{mmol})$. After $2 \mathrm{~h}$ at room temperature, water $(200 \mathrm{~mL})$ was added and the crude product extracted with EtOAc $(200 \mathrm{~mL})$ and $\mathrm{CH}_{2} \mathrm{Cl}_{2}(2 \times 200 \mathrm{~mL})$. The combined organic layer was dried over $\mathrm{MgSO}_{4}$, filtered, the solvent evaporated under reduced pressure and the product dried under a vacuum overnight. The crude Fmoc derivative was dissolved in DMA $(22 \mathrm{~mL})$ and the solution cooled to $0^{\circ} \mathrm{C}$ in an ice bath. A first portion of sulfamoyl chloride $(3.71 \mathrm{~g}, 32.11 \mathrm{mmol})$ was gradually added over $15 \mathrm{~min}$ and the mixture was allowed to react at room temperature. After $1 \mathrm{~h}$, the same amount of sulfamoyl chloride was added as described above, and the mixture stirred at room temperature for 3 additional hours. The mixture was then poured in a cool solution of brine and extracted with EtOAc $(3 \times 200 \mathrm{~mL})$. The combined organic layer was washed with brine $(1 \times 500 \mathrm{~mL})$, dried over $\mathrm{MgSO}_{4}$, and evaporated to dryness. Purification by flash chromatography with hexanes/acetone (7:3 to 6:4) yielded $4.05 \mathrm{~g}(72 \%)$ of $2 .{ }^{1} \mathrm{H}$ NMR (acetone-d $)$ ) $\delta$, ppm: $2.04-2.07$ (m, 2H), $3.35-3.38(\mathrm{~m}, 2 \mathrm{H}), 4.21$ (t, J = 6.9 Hz, 1H), 4.35 $(\mathrm{d}, \mathrm{J}=6.9 \mathrm{~Hz}, 2 \mathrm{H}), 6.62(\mathrm{bt}, 1 \mathrm{H}, \mathrm{NH}), 7.14-7.45(\mathrm{~m}, 8 \mathrm{H}), 7.68(\mathrm{~d}, \mathrm{~J}=7.4 \mathrm{~Hz}, 2 \mathrm{H}), 7.87(\mathrm{~d}, \mathrm{~J}=7.6 \mathrm{~Hz}, 2 \mathrm{H}) .{ }^{13} \mathrm{C}$ NMR (acetone- $\mathrm{d}_{6}$ ) $\delta$, ppm: 148.1, 141.0, 136.1, 133.1, 130.0, 121.8, 119.5, 118.9, 117.0, 114.0, 111.8, 57.7, 39.1, 34.0, 27.0.

\section{Synthesis of resin 3 (loading of sulfamate 2 on trityl resin)}

Trityl chloride resin $(2.51 \mathrm{~g})(1.10 \mathrm{mmol} / \mathrm{g}$ loading $)$ and sulfamate $2(1.45 \mathrm{~g})$ were added in a $50 \mathrm{~mL}$ peptide flask equipped with a three-way stopcock and swollen under argon in dry $\mathrm{CH}_{2} \mathrm{Cl}_{2}(24 \mathrm{~mL})$. Diisopropylethylamine (DIPEA) $(4.81 \mathrm{~mL})$ was then added and the mixture was stirred overnight at room temperature. The resin was filtered and washed with $\mathrm{CH}_{2} \mathrm{Cl}_{2}(3 \times 25 \mathrm{~mL}), \mathrm{MeOH}(3 \times 25 \mathrm{~mL})$, THF $(3 \times 25 \mathrm{~mL})$ and again with $\mathrm{CH}_{2} \mathrm{Cl}_{2}(3 \times 25 \mathrm{~mL})$, then dried overnight under a vacuum to afford $3.84 \mathrm{~g}$ of resin 3 . The coupling yield calculated by means of the mass increase was quantitative. Resin 3: FTIR ( $\mathrm{KBr}$ matrix) v, $\mathrm{cm}^{-1}: 1696$ (C=O, Fmoc group), 1350 and 1156 (sulfonamide). Gel-Phase ${ }^{13} \mathrm{C}$ NMR (150 $\mathrm{mg}$ resin swelled in $\mathrm{CD}_{2} \mathrm{Cl}_{2}$ /benzene- $\mathrm{d}_{6}$ with the following conditions: $\mathrm{d} 1-1.0 \mathrm{~s}, \mathrm{p} 1=30^{\circ}(3.0 \mu \mathrm{s}), \mathrm{aq}=430 \mathrm{~ms}, \mathrm{RG} 800$ $\mathrm{SI}=32 \mathrm{~K}) \delta$, ppm: 156.1, 144.0, 141.3, 137.7, 132.1, 125.0, 122.0, 119.9, 73.5, 66.2, 47.2, 40.8, 35.9.

\section{Library synthesis: Introducing the first level of molecular diversity}

A 96-well Teflon reaction vessel from Advanced ChemTechLabtech Manual Organic Synthesizer-Platform IV was used for the solid-phase synthesis. Small-volume peptide flasks or PD-10 columns (Amersham Biosciences, Upsala, Sweden) fitted with a three-way stopcock (Bio-Rad, Hercules, CA, USA) could alternatively be used. In 25 wells of a 96-well reaction block loaded with resin $3(25 \times 120 \mathrm{mg})$ was added a solution of $20 \%$ piperidine in $\mathrm{CH}_{2} \mathrm{Cl}_{2}(1.5 \mathrm{~mL})$ and the mixture was stirred at room temperature to hydrolyze the Fmoc. After $1 \mathrm{~h}$, the resins were filtered to remove the solvent, washed with $\mathrm{CH}_{2} \mathrm{Cl}_{2}(5 \times 2 \mathrm{~mL})$ and dried under a vacuum for $2 \mathrm{~h}$. Five stock solutions, each containing PyBOP (450 mg, $0.870 \mathrm{mmol}$ ) and $\mathrm{HOBt}(120 \mathrm{mg}, 0.870 \mathrm{mmol}$ ), as well as one of the Fmoc-protected amino acids from the $L$ series (alanine, valine, leucine, isoleucine or phenylalanine) $(0.870 \mathrm{mmol})$, were prepared in DMF $(7.5 \mathrm{~mL})$ and reacted 2 min with DIPEA $(0.3 \mathrm{~mL}, 1.74 \mathrm{mmol})$. Next, one of the stock solutions was added (in equal proportions of $1.5 \mathrm{~mL})$ in 
each of the 25 reaction vessels (five wells for each amino acid) containing the resin with the tyramine. The resins were stirred under argon for $3 \mathrm{~h}$, then filtered, washed with DMF $(3 \times 2 \mathrm{~mL})$ and $\mathrm{CH}_{2} \mathrm{Cl}_{2}(5 \times 2 \mathrm{~mL})$, and dried overnight under a vacuum to afford five groups $(5 \times 5)$ of resins $4 \mathbf{a}-4 \mathbf{e}$. FTIR (KBr matrix) $v, \mathrm{~cm}^{-1}: 1708-1709$ ( $\mathrm{C}=\mathrm{O}$, Fmoc group), 1656-1662 ( $\mathrm{C}=\mathrm{O}$, amide) and 1350 and 1156 (sulfonamide).

\section{Library synthesis: Introducing the second level of molecular diversity}

To the five groups of resins $4 \mathbf{a}-4 \mathbf{e}$ (25 wells) obtained above was added a solution of $20 \%$ piperidine in $\mathrm{CH}_{2} \mathrm{Cl}_{2}$ $(1.5 \mathrm{~mL})$ and the block was stirred at room temperature. After $1 \mathrm{~h}$, the resins were filtered, washed with $\mathrm{CH}_{2} \mathrm{Cl}_{2}(5 \times 3$ $\mathrm{mL})$ and dried under vacuum $(2 \mathrm{~h})$. Each of the five resins with distinct aminoacid diversity was reacted with a solution $(1.5 \mathrm{~mL})$ of carboxylic acid (propionic, isobutyric, $t$-butyl acetic, phenyl acetic or 3-cyclopentyl propionic) $(0.870$ mmol) activated with PyBrOP (405 mg, $0.870 \mathrm{mmol})$, HOBt $(120 \mathrm{mg}, 0.870 \mathrm{mmol})$ and DIPEA $(0.85 \mathrm{~mL}, 0.30 \mathrm{mmol})$ in DMF $(7.5 \mathrm{~mL})$. The 25 resins $(5 \times 5)$ were stirred for $3 \mathrm{~h}$ at room temperature, then filtered and washed with DMF ( 3 x $2 \mathrm{~mL}), \mathrm{CH}_{2} \mathrm{Cl}_{2}(5 \times 2 \mathrm{~mL})$, THF ( $\left.3 \times 2 \mathrm{~mL}\right), \mathrm{THF} / \mathrm{H}_{2} \mathrm{O}(3 \times 2 \mathrm{~mL}), \mathrm{H}_{2} \mathrm{O}(3 \times 2 \mathrm{~mL}), \mathrm{H}_{2} \mathrm{O} / \mathrm{MeOH}(3 \times 2 \mathrm{~mL})$ and $\mathrm{MeOH}$, and were dried overnight under vacuum to afford 25 different resins 5aa-5ee. FTIR (KBr matrix) v, $\mathrm{cm}^{-1}: 1640-1658$ $(\mathrm{C}=\mathrm{O}$, amides $)$.

\section{Cleavage strategy providing phenol derivatives (Nucleophilic cleavage)}

To each of the 25 resins 5aa-5ee in their reaction vessels was added a solution of $30 \%$ diethylamine (DEA) in THF $(1 \mathrm{~mL})$ and the resins were stirred under argon. After $24 \mathrm{~h}$ at room temperature, $1 \mathrm{~mL}$ of $30 \%$ DEA/THF solution was added and the resins were stirred for 24 additional hours. The resins were then filtered under vacuum, washed with $30 \%$ DEA in THF $(2 \times 1.5 \mathrm{~mL})$, and the filtrates were collected in pre-weighted glass tubes. The solvent was evaporated in a SpeedVac apparatus, THF $(3 \mathrm{~mL})$ was then added to each tube and the solutions were evaporated again $(2 \mathrm{x})$. The procedure was repeated with $\mathrm{Et}_{2} \mathrm{O}$. The crude products were dried for $48 \mathrm{~h}$ under vacuum pump to afford phenol derivatives 6-30. A sampling of 10 compounds from the 25 library members was characterized by ${ }^{1} \mathrm{H}$ NMR and MS. Purity was also assessed by quantitative ${ }^{1} \mathrm{H}$ NMR (Table 1 ).

$\mathrm{N}$-[2-(4-hydroxyphenyl)-ethyl]-2-propionylamino-propionamide (6): ${ }^{1} \mathrm{H}$ NMR (DMSO-d $\left.{ }_{6}\right) \delta$, ppm: $9.20(\mathrm{~s}, 1 \mathrm{H}, \mathrm{OH})$, 7.90 - $7.86(\mathrm{~m}, 2 \mathrm{H}, \mathrm{NH}), 6.98(\mathrm{~d}, 2 \mathrm{H}, \mathrm{J}=8.4 \mathrm{~Hz}), 6.66(\mathrm{~d}, 2 \mathrm{H}, \mathrm{J}=8.5 \mathrm{~Hz}), 4.23-4.16(\mathrm{~m}, 1 \mathrm{H}), 3.24-3.13(\mathrm{~m}, 2 \mathrm{H})$, $2.57(\mathrm{t}, 2 \mathrm{H}, 7.4 \mathrm{~Hz}), 2.11(\mathrm{q}, 2 \mathrm{H}, \mathrm{J}=7.6 \mathrm{~Hz}), 1.15-1.12(\mathrm{~m}, 1 \mathrm{H}), 0.97(\mathrm{t}, 3 \mathrm{H}, 7.6 \mathrm{~Hz})$. MS/EI $\left(\mathrm{C}_{14} \mathrm{H}_{20} \mathrm{~N}_{2} \mathrm{O}_{3}\right)$ calculated: 264.1; observed: $265.1(\mathrm{M}+\mathrm{H})^{+}$.

3-Cyclopentyl-N-\{1-[2-(4-hydroxyphenyl)-ethylcarbamoyl]-ethyl $\}$-propionamide (10): ${ }^{1} \mathrm{H}$ NMR (DMSO-d 6 ) $\delta$, ppm: 9.20 (s, 1H, OH), 7.92 (bd, 1H, NH, J = 7.6 Hz), 7.85 (bt, 1H, NH, J = 5.6 Hz), 6.97 (d, 2H, J = 8.4 Hz), 6.66 (d, 2H, J $=8.4 \mathrm{~Hz}), 4.23-4.16(\mathrm{~m}, 1 \mathrm{H}), 3.26-3.11(\mathrm{~m}, 2 \mathrm{H}), 2.56(\mathrm{t}, 2 \mathrm{H}, \mathrm{J}=7.3 \mathrm{~Hz}), 2.11(\mathrm{t}, 2 \mathrm{H}, \mathrm{J}=7.6 \mathrm{~Hz}), 1.74-1.42(\mathrm{~m}$, $9 \mathrm{H}), 1.12(\mathrm{~d}, 3 \mathrm{H}, \mathrm{J}=7.1 \mathrm{~Hz}), 1.10-1.00(\mathrm{~m}, 2 \mathrm{H})$. MS/EI $\left(\mathrm{C}_{19} \mathrm{H}_{28} \mathrm{~N}_{2} \mathrm{O}_{3}\right)$ calculated: 332.2; observed: $333.1(\mathrm{M}+\mathrm{H})^{+}$.

N-[2-(4-hydroxyphenyl)-ethyl]-2-isobutyrylamino-3-methyl-butyramide (12): ${ }^{1} \mathrm{H}$ NMR (DMSO-d $\left.{ }_{6}\right) \delta$, ppm: 9.21 (s, 1H, OH), 7.99 (bt, 1H, NH, J = 5.5 Hz), $7.72(\mathrm{bd}, 1 \mathrm{H}, \mathrm{NH}, \mathrm{J}=9.1 \mathrm{~Hz}), 6.98(\mathrm{~d}, 2 \mathrm{H}, \mathrm{J}=8.4 \mathrm{~Hz}), 6.65(\mathrm{~d}, 2 \mathrm{H}, \mathrm{J}=8.4 \mathrm{~Hz})$, $4.07(\mathrm{dd}, 1 \mathrm{H}, \mathrm{J}=7.4 \mathrm{~Hz}$ and $\mathrm{J}=9.0 \mathrm{~Hz}), 3.31-3.14(\mathrm{dm}, 2 \mathrm{H}), 2.60-2.55(\mathrm{~m}, 2 \mathrm{H}), 1.93-1.83(\mathrm{~m}, 1 \mathrm{H}), 1.24-1.22(\mathrm{~m}$, $1 \mathrm{H}), 0.98(\mathrm{q}, 6 \mathrm{H}, \mathrm{J}=6.8 \mathrm{~Hz}), 0.78(\mathrm{~d}, 6 \mathrm{H}, \mathrm{J}=6.8 \mathrm{~Hz})$. MS/EI $\left(\mathrm{C}_{17} \mathrm{H}_{26} \mathrm{~N}_{2} \mathrm{O}_{3}\right)$ calculated: 306.2; observed: $307.1(\mathrm{M}+\mathrm{H})^{+}$.

2-(Cyclopentylpropionylamino)-N-[2-(4-hydroxyphenyl)-ethyl]-3-methyl-butyramide (15): ${ }^{1} \mathrm{H}$ NMR (DMSO-d $\left.{ }_{6}\right) \delta$, ppm: 9.19 (s, 1H, OH), 7.97 (bt, 1H, NH, J = 5.5 Hz), 7.79 (bd, 1H, NH, J = 9.0 Hz), 6.98 (d, 2H, J = 8.4 Hz), 6.66 $(\mathrm{d}, 2 \mathrm{H}, \mathrm{J}=8.4 \mathrm{~Hz}), 4.08(\mathrm{dd}, 1 \mathrm{H}, \mathrm{J}=7.3 \mathrm{~Hz}$ and $\mathrm{J}=8.9 \mathrm{~Hz}), 3.26-3.15(\mathrm{~m}, 2 \mathrm{H}), 2.57(\mathrm{t}, 2 \mathrm{H}, \mathrm{J}=6.5 \mathrm{~Hz}), 2.23-2.09$ $(\mathrm{m}, 2 \mathrm{H}), 1.73-1.43(\mathrm{~m}, 9 \mathrm{H}), 1.24-1.22(\mathrm{~m}, 1 \mathrm{H}), 1.10-1.01(\mathrm{~m}, 2 \mathrm{H}), 0.78(\mathrm{~d}, 6 \mathrm{H}, \mathrm{J}=6.7 \mathrm{~Hz}) . \mathrm{MS} / \mathrm{EI}\left(\mathrm{C}_{21} \mathrm{H}_{32} \mathrm{~N}_{2} \mathrm{O}_{3}\right)$ calculated: 360.2 ; observed: $361.2(\mathrm{M}+\mathrm{H})^{+}$.

4-Methyl-2-propionylaminopentanoic acid [2-(4-hydroxyphenyl)-ethyl]-amide (16): ${ }^{1} \mathrm{H}$ NMR (DMSO-d 6 ) $\delta$, ppm: 9.20 $(\mathrm{s}, 1 \mathrm{H}, \mathrm{OH}), 7.93(\mathrm{bt}, 1 \mathrm{H}, \mathrm{NH}, \mathrm{J}=5.6 \mathrm{~Hz}), 7.85(\mathrm{bd}, 1 \mathrm{H}, \mathrm{NH}, \mathrm{J}=8.4 \mathrm{~Hz}), 6.97(\mathrm{~d}, 2 \mathrm{H}, \mathrm{J}=8.4 \mathrm{~Hz}), 6.66(\mathrm{~d}, 2 \mathrm{H}, \mathrm{J}=$ $8.4 \mathrm{~Hz}$ ), $4.25-4.19(\mathrm{~m}, 1 \mathrm{H}), 3.25-3.14(\mathrm{~m}, 2 \mathrm{H}), 2.56(\mathrm{t}, 2 \mathrm{H}, \mathrm{J}=7.3 \mathrm{~Hz}), 2.11$ (qd, 2H, J = 2.0 Hz and J = 7.5 Hz), $1.53-1.46(\mathrm{~m}, 1 \mathrm{H}), 1.25-1.21(\mathrm{~m}, 2 \mathrm{H}), 0.97,(\mathrm{t}, 3 \mathrm{H}, \mathrm{J}=7.6 \mathrm{~Hz}), 0.83(\mathrm{dd}, 6 \mathrm{H}, \mathrm{J}=6.6 \mathrm{~Hz}$ and $\mathrm{J}=18.2 \mathrm{~Hz})$. MS/EI $\left(\mathrm{C}_{17} \mathrm{H}_{26} \mathrm{~N}_{2} \mathrm{O}_{3}\right)$ calculated: 306.2; observed: $307.1(\mathrm{M}+\mathrm{H})^{+}$.

2-(3,3-Dimethylbutyrylamino)-4-methylpentanoic acid [2-(4-hydroxyphenyl)-ethyl]-amide (18): ${ }^{1} \mathrm{H}$ NMR (DMSO-d $)$ $\delta$, ppm: 9.20 (s, 1H, OH), 7.90 (bt, 1H, NH, J = 5.4 Hz), 7.80 (bd, 1H, NH, J = 8.3 Hz), 6.97 (d, 2H, J = 8.4 Hz), 6.66 $(\mathrm{d}, 2 \mathrm{H}, \mathrm{J}=8.5 \mathrm{~Hz}), 4.26-4.20(\mathrm{~m}, 1 \mathrm{H}), 3.26-3.14(\mathrm{~m}, 2 \mathrm{H}), 2.58-2.54(\mathrm{~m}, 2 \mathrm{H}), 2.04-1.91(\mathrm{~m}, 2 \mathrm{H}), 1.55-1.51(\mathrm{~m}$, $1 \mathrm{H}), 1.26-1.21(\mathrm{~m}, 2 \mathrm{H}), 0.94(\mathrm{~s}, 9 \mathrm{H}), 0.83(\mathrm{dd}, 6 \mathrm{H}, \mathrm{J}=6.6 \mathrm{~Hz}$ and $\mathrm{J}=19.0 \mathrm{~Hz})$. MS/EI $\left(\mathrm{C}_{20} \mathrm{H}_{32} \mathrm{~N}_{2} \mathrm{O}_{3}\right)$ calculated: 348.5 ; observed: $349.3(\mathrm{M}+\mathrm{H})^{+}$. 


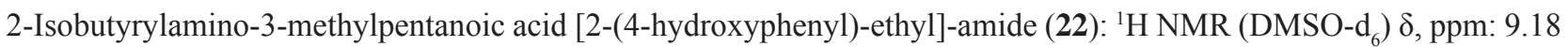
$(\mathrm{s}, 1 \mathrm{H}, \mathrm{OH}), 8.00(\mathrm{bd}, 1 \mathrm{H}, \mathrm{NH}, \mathrm{J}=9.1 \mathrm{~Hz}), 7.72(\mathrm{bt}, 1 \mathrm{H}, \mathrm{NH}, \mathrm{J}=5.5 \mathrm{~Hz}), 6.98(\mathrm{~d}, 2 \mathrm{H}, \mathrm{J}=8.5 \mathrm{~Hz}), 6.65(\mathrm{~d}, 2 \mathrm{H}, \mathrm{J}=8.5$ $\mathrm{Hz}), 4.10(\mathrm{t}, 1 \mathrm{H}, 8.8 \mathrm{~Hz}), 3.24-3.16(\mathrm{~m}, 2 \mathrm{H}), 2.59-2.55(\mathrm{~m}, 2 \mathrm{H}), 1.70-1.60(\mathrm{~m}, 1 \mathrm{H}), 1.38-1.32(\mathrm{~m}, 1 \mathrm{H}), 1.07-1.00$ $(\mathrm{m}, 2 \mathrm{H}), 0.97(\mathrm{dd}, 6 \mathrm{H}, \mathrm{J}=6.8 \mathrm{~Hz}$ and $\mathrm{J}=11.0 \mathrm{~Hz}), 0.78(\mathrm{t}, 3 \mathrm{H}, \mathrm{J}=7.3 \mathrm{~Hz}), 0.75(\mathrm{~d}, 3 \mathrm{H}, \mathrm{J}=6.8 \mathrm{~Hz}) . \mathrm{MS} / \mathrm{EI}\left(\mathrm{C}_{18} \mathrm{H}_{28} \mathrm{~N}_{2} \mathrm{O}_{3}\right)$ calculated: 320.2 ; observed: $321.1(\mathrm{M}+\mathrm{H})^{+}$.

3-Methyl-2-phenylacetylaminopentanoic acid [2-(4-hydroxyphenyl)-ethyl]-amide (24): ${ }^{1} \mathrm{H}$ NMR (DMSO-d $) \delta$, ppm: $9.19(\mathrm{~s}, 1 \mathrm{H}, \mathrm{OH}), 7.99(\mathrm{bd}, 1 \mathrm{H}, \mathrm{NH}, \mathrm{J}=9.0 \mathrm{~Hz}), 7.81(\mathrm{bt}, 1 \mathrm{H}, \mathrm{NH}, \mathrm{J}=5.5 \mathrm{~Hz}), 7.31-7.17(\mathrm{~m}, 5 \mathrm{H}), 6.98(\mathrm{~d}, 2 \mathrm{H}, \mathrm{J}=8.2$ $\mathrm{Hz}), 6.65(\mathrm{~d}, 2 \mathrm{H}, \mathrm{J}=8.4 \mathrm{~Hz}), 4.10(\mathrm{~m}, 1 \mathrm{H}), 3.25-3.17(\mathrm{~m}, 2 \mathrm{H}), 2.57(\mathrm{bt}, 2 \mathrm{H}), 2.20-2.08(\mathrm{~m}, 2 \mathrm{H}), 1.37-1.30(\mathrm{~m}, 1 \mathrm{H})$, $1.09-0.99(\mathrm{~m}, 2 \mathrm{H}), 0.79(\mathrm{~d}, 3 \mathrm{H}, \mathrm{J}=7.1 \mathrm{~Hz}), 0.74(\mathrm{t}, 3 \mathrm{H}, \mathrm{J}=6.5 \mathrm{~Hz})$. MS/EI $\left(\mathrm{C}_{22} \mathrm{H}_{28} \mathrm{~N}_{2} \mathrm{O}_{3}\right)$ calculated: 368.2 ; observed: $369.3(\mathrm{M}+\mathrm{H})^{+}$.

$\mathrm{N}$-\{1-[2-(4-hydroxyphenyl)-ethylcarbamoyl]-2-phenylethyl $\}$-3,3-dimethylbutyramide (28): ${ }^{1} \mathrm{H}$ NMR (DMSO-d 6 ) $\delta$, ppm: 9.22 (s, 1H, OH), 7.98 (bt, 1H, NH, J = 5.4 Hz), 7.92 (bd, 1H, NH, J = 8.5 Hz), 7.26- 7.14 (m, 5H), 6.97 (d, 2H, $\mathrm{J}=8.5 \mathrm{~Hz}), 6.66(\mathrm{~d}, 2 \mathrm{H}, \mathrm{J}=8.4 \mathrm{~Hz}), 4.50-4.44(\mathrm{~m}, 1 \mathrm{H}), 3.26-3.15(\mathrm{~m}, 2 \mathrm{H}), 2.73-2.67(\mathrm{~m}, 2 \mathrm{H}), 2.57-2.50(\mathrm{~m}$, $2 \mathrm{H}), 1.92(\mathrm{~s}, 2 \mathrm{H}), 0.80(\mathrm{~s}, 9 \mathrm{H}) . \mathrm{MS} / \mathrm{EI}\left(\mathrm{C}_{23} \mathrm{H}_{30} \mathrm{~N}_{2} \mathrm{O}_{3}\right)$ calculated: 382.2 ; observed: $383.2(\mathrm{M}+\mathrm{H})^{+}$.

N-[2-(4-hydroxyphenyl)-ehtyl]-3-phenyl-2phenylacetylaminopropionamide (29): ${ }^{1} \mathrm{H}$ NMR (DMSO-d 6 ) $\delta$, ppm: 9.19 (s, $1 \mathrm{H}, \mathrm{OH}), 8.33(\mathrm{bd}, 1 \mathrm{H}, \mathrm{NH}), 8.08(\mathrm{bt}, 1 \mathrm{H}, \mathrm{NH}), 7.26-7.06(\mathrm{~m}, 10 \mathrm{H}), 6.97(\mathrm{~d}, 2 \mathrm{H}, \mathrm{J}=8.4 \mathrm{~Hz}), 6.66(\mathrm{~d}, 2 \mathrm{H}, \mathrm{J}=8.3$ $\mathrm{Hz}), 4.45-4.42(\mathrm{~m}, 1 \mathrm{H}), 3.26-3.14(\mathrm{~m}, 2 \mathrm{H}), 2.75-2.66(\mathrm{~m}, 2 \mathrm{H}), 2.56-2.50(\mathrm{~m}, 2 \mathrm{H}), 2.04-1.99(\mathrm{~m}, 2 \mathrm{H}) . \mathrm{MS} / \mathrm{EI}$ $\left(\mathrm{C}_{25} \mathrm{H}_{26} \mathrm{~N}_{2} \mathrm{O}_{3}\right)$ calculated: 402.2 ; observed: $403.3(\mathrm{M}+\mathrm{H})^{+}$.

\section{Cleavage strategy providing sulfamate derivatives (Acidic cleavage)}

To each of the 25 resins 5aa-5ee previously submitted to nucleophilic cleavage was added a solution of $30 \%$ hexafluoroisopropanol (HFIP) in $\mathrm{CH}_{2} \mathrm{Cl}_{2}(1.5 \mathrm{~mL})$ and the resins were stirred under argon. After $6 \mathrm{~h}$ at room temperature, the resins were filtered under vacuum, washed with $30 \% \mathrm{HFIP}$ in $\mathrm{CH}_{2} \mathrm{Cl}_{2}(2 \times 1 \mathrm{~mL})$ and THF $(2 \times 1 \mathrm{~mL})$, and the filtrate was collected in pre-weighted tubes. The solvent was evaporated in a SpeedVac apparatus, THF $(2 \times 3 \mathrm{~mL})$ was then added to each tube and the solutions were evaporated again. The procedure was repeated with $\mathrm{Et}_{2} \mathrm{O}$. The crude products were dried $48 \mathrm{~h}$ under vacuum pump to afford sulfamate derivatives 31-55. A sampling of 10 compounds from the 25 library members was characterized by ${ }^{1} \mathrm{H}$ NMR and MS. Purity was also assessed by quantitative ${ }^{1} \mathrm{H}$ NMR (Table 2).

Sulfamic acid 4-[2-(2-propionylamino-propionylamino)-ethyl]-phenyl ester (31): ${ }^{1} \mathrm{H}$ NMR (DMSO-d $)$ ) $\delta$, ppm: 7.98 $7.86\left(\mathrm{~m}, 3 \mathrm{H}, \mathrm{NH}\right.$ and $\left.\mathrm{NH}_{2}\right), 7.31-7.17(\mathrm{~m}, 4 \mathrm{H}), 4.23-4.17(\mathrm{~m}, 1 \mathrm{H}), 3.33-3.21(\mathrm{~m}, 2 \mathrm{H}), 2.72(\mathrm{t}, 2 \mathrm{H}, \mathrm{J}=7.3 \mathrm{~Hz}), 2.11$ $(\mathrm{q}, 2 \mathrm{H}, \mathrm{J}=7.6 \mathrm{~Hz}), 1.15-1.12(\mathrm{~m}, 3 \mathrm{H}), 0.97(\mathrm{t}, 3 \mathrm{H} . \mathrm{J}=7.6 \mathrm{~Hz})$. MS/EI $\left(\mathrm{C}_{14} \mathrm{H}_{21} \mathrm{~N}_{3} \mathrm{O}_{5} \mathrm{~S}\right)$ calculated: 343.2; observed: $344.1(\mathrm{M}+\mathrm{H})^{+}$.

Sulfamic acid 4-\{2-[2-(3-cyclopentylpropionylamino)-propionylamino]-ethyl $\}$-phenyl ester (35): ${ }^{1} \mathrm{H}$ NMR (DMSO-d $)$ $\delta$, ppm: $7.98-7.92\left(\mathrm{~m}, 3 \mathrm{H}, \mathrm{NH}\right.$ and $\left.\mathrm{NH}_{2}\right), 7.31-7.17(\mathrm{~m}, 4 \mathrm{H}), 4.23-4.16(\mathrm{~m}, 1 \mathrm{H}), 3.30-3.22(\mathrm{~m}, 2 \mathrm{H}), 2.71(\mathrm{t}, 2 \mathrm{H}, \mathrm{J}=$

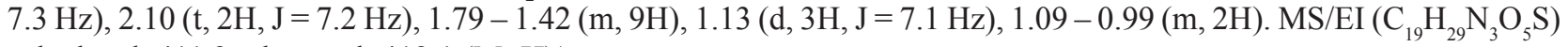
calculated: 411.2 ; observed: $412.1(\mathrm{M}+\mathrm{H})^{+}$.

Sulfamic acid 4[2-(2-isobutyrylamino-3-methylbutyrylamino)-ethyl]-phenyl ester (37): ${ }^{1} \mathrm{H}$ NMR (DMSO-d $) \delta$, ppm: 8.08 (bt, 1H, NH, J = 5.4 Hz), 7.97 (bs, 1H, NH $), 7.74$ (bd, 1H, NH, J = 8.9 Hz), $7.31-7.16$ (m, 4H), 4.07 (dd, 1H, J = $7.6 \mathrm{~Hz}$ and $\mathrm{J}=9.1 \mathrm{~Hz}), 3.33-3.19(\mathrm{~m}, 2 \mathrm{H}), 2.73(\mathrm{t}, 2 \mathrm{H}, \mathrm{J}=5.9 \mathrm{~Hz}), 1.93-1.83(\mathrm{~m}, 1 \mathrm{H}), 1.25-1.22(\mathrm{~m}, 1 \mathrm{H}), 0.98(\mathrm{q}$, $6 \mathrm{H}, \mathrm{J}=6.8 \mathrm{~Hz}), 0.79(\mathrm{~d}, 6 \mathrm{H}, \mathrm{J}=6.6 \mathrm{~Hz})$. MS/EI $\left(\mathrm{C}_{17} \mathrm{H}_{27} \mathrm{~N}_{3} \mathrm{O}_{5} \mathrm{~S}\right)$ calculated: 385.2; observed: $386.1(\mathrm{M}+\mathrm{H})^{+}$.

Sulfamic acid 4-\{2-[2-(3-cyclopentylpropionylamino)-3-methylbutyrylamino]-ethyl\}-phenyl ester (40): ${ }^{1} \mathrm{H}$ NMR $\left(\mathrm{DMSO}_{6}\right.$ ) $\delta$, ppm: 8.06 (bt, 1H, NH, J = $\left.4.9 \mathrm{~Hz}\right), 7.96\left(\mathrm{bs}, 1 \mathrm{H}, \mathrm{NH}_{2}\right), 7.81$ (bd, 1H, NH, J = 8.9 Hz), $7.33-7.16$ (m, $4 \mathrm{H}), 4.08-4.02(\mathrm{~m}, 1 \mathrm{H}), 3.32-3.19(\mathrm{~m}, 2 \mathrm{H}), 2.72(\mathrm{t}, 2 \mathrm{H}, \mathrm{J}=7.2 \mathrm{~Hz}), 2.23-2.08(\mathrm{~m}, 2 \mathrm{H}), 1.76-1.41(\mathrm{~m}, 9 \mathrm{H}), 1.26$ $-1.21(\mathrm{~m}, 1 \mathrm{H}), 1.11-1.01(\mathrm{~m}, 2 \mathrm{H}), 0.78(\mathrm{dd}, 6 \mathrm{H}, \mathrm{J}=2.1 \mathrm{~Hz}$ and $\mathrm{J}=6.6 \mathrm{~Hz})$. MS/EI $\left(\mathrm{C}_{21} \mathrm{H}_{33} \mathrm{~N}_{3} \mathrm{O}_{5} \mathrm{~S}\right)$ calculated: 439.2; observed: $440.2(\mathrm{M}+\mathrm{H})^{+}$.

Sulfamic acid 4-[2-(4-methyl-2-propionylaminopentanoylamino)-ethyl]-phenyl ester (41): ${ }^{1} \mathrm{H}$ NMR (DMSO-d $) \delta$, ppm: 8.02 (bt, $1 \mathrm{H}, \mathrm{NH}, \mathrm{J}=5.8 \mathrm{~Hz}), 7.96\left(\mathrm{bs}, 1 \mathrm{H}, \mathrm{NH}_{2}\right), 7.86(\mathrm{bt}, 1 \mathrm{H}, \mathrm{NH}, \mathrm{J}=8.2 \mathrm{~Hz}), 7.30-7.16(\mathrm{~m}, 4 \mathrm{H}), 4.29-4.19(\mathrm{~m}, 1 \mathrm{H})$, $3.31-3.20(\mathrm{~m}, 2 \mathrm{H}), 2.71(\mathrm{t}, 2 \mathrm{H}, \mathrm{J}=7.4 \mathrm{~Hz}), 2.14-2.07(\mathrm{~m}, 2 \mathrm{H}), 1.54-1.44(\mathrm{~m}, 1 \mathrm{H}), 1.25-1.13(\mathrm{~m}, 2 \mathrm{H}), 0.97(\mathrm{t}, 3 \mathrm{H}$, $\mathrm{J}=7.6 \mathrm{~Hz}), 0.83(\mathrm{dd}, 6 \mathrm{H}, \mathrm{J}=6.5 \mathrm{~Hz}$ and $\mathrm{J}=17.6 \mathrm{~Hz})$. MS/EI $\left(\mathrm{C}_{17} \mathrm{H}_{27} \mathrm{~N}_{3} \mathrm{O}_{5} \mathrm{~S}\right)$ calculated: 385.2 ; observed: $386.1(\mathrm{M}+\mathrm{H})^{+}$. 
Sulfamic acid 4-\{2-[2-(3,3-dimethylbutyrylamino)-4-methylpentanoylamino]-ethyl\}-phenyl ester (43): ${ }^{1} \mathrm{H}$ NMR $\left(\mathrm{DMSO}_{6}\right.$ ) $\delta$, ppm: 8.01 (bt, 1H, NH), 7.97 (bs, 1H, NH ), 7.83 (bd, 1H, NH, J = 8.0 Hz), $7.31-7.16$ (m, 4H), $4.29-$ $4.20(\mathrm{~m}, 1 \mathrm{H}), 3.32-3.21(\mathrm{~m}, 2 \mathrm{H}), 2.71(\mathrm{t}, 2 \mathrm{H}, \mathrm{J}=7.0 \mathrm{~Hz}), 2.05-1.95(\mathrm{~m}, 2 \mathrm{H}), 1.58-1.47(\mathrm{~m}, 1 \mathrm{H}), 1.25-1.14(\mathrm{~m}$, $2 \mathrm{H}), 0.94(\mathrm{~s}, 9 \mathrm{H}), 0.84(\mathrm{q}, 6 \mathrm{H}, \mathrm{J}=6.4 \mathrm{~Hz}) . \mathrm{MS} / \mathrm{EI}\left(\mathrm{C}_{20} \mathrm{H}_{33} \mathrm{~N}_{3} \mathrm{O}_{5} \mathrm{~S}\right)$ calculated: 427.2; observed: $428.1(\mathrm{M}+\mathrm{H})^{+}$.

Sulfamic acid 4-[2-(2-isobutyrylamino-3-methylpentanoylamino)-ethyl]-phenyl ester (47): ${ }^{1} \mathrm{H}$ NMR (DMSO-d $\left.{ }_{6}\right) \delta$, ppm: 8.09 (bt, 1H, NH, J = 5.3 Hz), 7.97 (bs, $1 \mathrm{H}, \mathrm{NH}_{2}$ ), 7.75 (bd, 1H, NH, J = 9.1 Hz), $7.31-7.16(\mathrm{~m}, 4 \mathrm{H}), 4.10(\mathrm{t}, 1 \mathrm{H}$, $\mathrm{J}=8.5 \mathrm{~Hz}), 3.33-3.19(\mathrm{~m}, 2 \mathrm{H}), 2.72(\mathrm{td}, 2 \mathrm{H}, \mathrm{J}=2.9 \mathrm{~Hz}$ and $\mathrm{J}=7.3 \mathrm{~Hz}), 1.71-1.61(\mathrm{~m}, 1 \mathrm{H}), 1.39-1.32(\mathrm{~m}, 1 \mathrm{H})$,

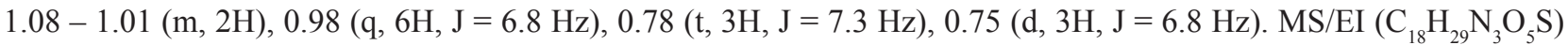
calculated: 399.2; observed: $400.1(\mathrm{M}+\mathrm{H})^{+}$.

Sulfamic acid 4-[2-(3-methyl-2-phenylacetylamino)-3-phenylpropionylamino)-ethyl]-phenyl ester (49): ${ }^{1} \mathrm{H}$ NMR $\left.\left(\mathrm{DMSO}_{6} \text { ) } \delta \text {, ppm: } 8.08 \text { (bt, 1H, NH, J = 4.9 Hz), } 7.97 \text { (bs, 1H, NH}\right)_{2}\right), 7.83$ (bd, 1H, NH, J = 8.9 Hz), $7.31-7.16$ (m, 9H), $4.10(\mathrm{~m}, 1 \mathrm{H}), 3.32-3.19(\mathrm{~m}, 2 \mathrm{H}), 2.71(\mathrm{t}, 2 \mathrm{H}, \mathrm{J}=7.0 \mathrm{~Hz}), 2.20-2.07(\mathrm{~m}, 2 \mathrm{H}), 1.38-1.31(\mathrm{~m}, 1 \mathrm{H}), 1.09-0.99(\mathrm{~m}$, $2 \mathrm{H}), 0.78(\mathrm{t}, 3 \mathrm{H}, \mathrm{J}=7.4 \mathrm{~Hz}), 0.73(\mathrm{~d}, 3 \mathrm{H}, \mathrm{J}=5.5 \mathrm{~Hz})$. MS/EI $\left(\mathrm{C}_{22} \mathrm{H}_{29} \mathrm{~N}_{3} \mathrm{O}_{5} \mathrm{~S}\right)$ calculated: 447.2; observed: $448.2(\mathrm{M}+\mathrm{H})^{+}$.

Sulfamic acid 4-\{2-[2-(3,3-dimethylbutyrylamino)-3-phenylpropionylamino]-ethyl\}-phenyl ester (53): ${ }^{1} \mathrm{H}$ NMR $\left.\left(\mathrm{DMSO}_{6} \text { ) } \delta \text {, ppm: } 8.06 \text { (bt, 1H, NH, J = 6.4 Hz), } 7.96 \text { (bs, 1H, NH}\right)_{2}\right), 7.94$ (bd, 1H, NH, J = 8.5 Hz), $7.29-7.15$ (m, $9 \mathrm{H}), 4.52-4.44(\mathrm{~m}, 1 \mathrm{H}), 3.29-3.21(\mathrm{~m}, 2 \mathrm{H}), 2.97-2.86(\mathrm{~m}, 2 \mathrm{H}), 2.72-2.69(\mathrm{~m}, 2 \mathrm{H}), 2.00(\mathrm{~s}, 2 \mathrm{H}), 0.80(\mathrm{~s}, 9 \mathrm{H})$. MS/ EI $\left(\mathrm{C}_{23} \mathrm{H}_{21} \mathrm{~N}_{3} \mathrm{O}_{5} \mathrm{~S}\right)$ calculated: 461.2 ; observed: $462.1(\mathrm{M}+\mathrm{H})^{+}$.

Sulfamic acid 4[2-(3-phenyl-2-phenylacetylaminopropionylamino)-ethyl]-phenyl ester (54): ${ }^{1} \mathrm{H}$ NMR (DMSO-d $) \delta$, ppm: 8.37-7.94 (m, 3H, NH and $\left.\mathrm{NH}_{2}\right), 7.30-7.05(\mathrm{~m}, 14 \mathrm{H}), 4.45(\mathrm{td}, 1 \mathrm{H}, \mathrm{J}=4.7 \mathrm{~Hz}$ and $\mathrm{J}=9.1 \mathrm{~Hz}), 3.31-3.19(\mathrm{~m}$, $2 \mathrm{H}), 2.96-2.71(\mathrm{~m}, 2 \mathrm{H}), 2.71-2.64(\mathrm{~m}, 2 \mathrm{H}), 2.05-1.99(\mathrm{~m}, 2 \mathrm{H})$. MS/EI $\left(\mathrm{C}_{25} \mathrm{H}_{27} \mathrm{~N}_{3} \mathrm{O}_{5} \mathrm{~S}\right)$ calculated: 481.2 ; observed: $482.1(\mathrm{M}+\mathrm{H})^{+}$.

\section{Acknowledgments}

We are grateful to the Canadian Institutes of Health Research for their financial support, to Mrs. Marie-Claude Trottier for NMR analyses and to Mrs. Micheline Harvey for careful reading of the manuscript.

\section{References}

1. Spillane, W.J.; Ryder, C.A.; Walsh, R.M., Curran, P.J., Concagh, D.G.; Wall, S.N. Sulfamate sweeteners. Food Chemistry, 1996, 56, pp. 255-261.

2. Spillane, W; Malaubier, J.F. Sulfamic acid and its N- and O-substituted derivatives. Chemical Reviews, 2014, 114, pp. 2507-2586.

3. Winum, J-Y.; Scozzafava, A.; Montero, J.-L.; Supuran, C.T. Therapeutic applications of sulfamate. Expert Opinion on Therapeutic Patents, 2004, 14, pp. 1273-1308.

4. Maryanoff, B.E.; Costanzo, M.J.; Nortey, S.O.; Greco, M.N.; Shank, R.P.; Schupsky, J.J.; Ortegon, M.P.; Vaught, J.L. Structure-activity studies on anticonvulsant sugar sulfamates related to topiramate. Enhanced potency with cyclic sulfate derivatives. Journal of Medicinal Chemistry, 1998, 41, pp. 1315-1343.

5. Pastorekova, S.; Parkkila, S.; Pastorek, J.; Supuran, C.T. Carbonic anhydrase: Current state of the art, therapeutic applications and future prospects. Journal of Enzyme Inhibition and Medicinal Chemistry, 2004, 19, pp. 199-229.

6. Winum, J.Y.; Scozzafava, A.; Montero, J.L.; Supuran C.T. Sulfamates and their therapeutic potential. Medicinal Research Reviews, 2005, 25, pp. 186-228.

7. Mostafa, Y.A.; Taylor, S.D. Steroid derivatives as inhibitors of steroid sulfatase. The Journal of Steroid Biochemistry and Molecular Biology, 2013, 137, pp. 183-198.

8. Purohit, A.; Foster, P.A. Steroid sulfatase inhibitors for estrogen-and androgen-dependent cancers. Journal of Endocrinology, 2012, 212, pp. 99-110.

9. Maltais, R.; Poirier, D. Steroid sulfates inhibitors: A review covering the promising 2000-2010 decade. Steroids, 2011, 76, pp. 929-948.

10. Nussbaumer, P.; Billich, A. Steroid sulfatase inhibitors. Medicinal Research Reviews, 2004, 24, pp. 529-576.

11. Purohit, A.; Woo, L.W.L.; Chander, S.K.; Newman, S.P.; Ireson, C.; Ho, Y.; Grasso, A.; Leese, M.P.; Potter, B.V.L.; Reed, M.J. Steroid sulphatase inhibitors for breast cancer therapy. The Journal of Steroid Biochemistry and Molecular Biology, 2003, 86, pp. 423-432.

12. Selcer, K.W.; Kabler, H.; Sarap, J.; Xiao, Z.; Li, P.-K. Inhibition of steryl sulfatase activity in LNCaP human prostate cancer cells. Steroids, 2002, 67, pp. 821-826.

13. Hoffmann, R.; Rot, A.; Niiyama, S.; Billich, A. Steroid Sulfatase in the Human Hair Follicle Concentrates in the Dermal Papilla. Journal of Investigative Dermatology, 2001, 117, pp. 1342-1348. 
14. Johnson, D.A.; Wu, T.-H.; Li, P.-K.; Maher, T.J. The effect of steroid sulfatase inhibition on learning and spatial memory. Brain Research, 2000, 865, pp. 286-290.

15. Parker, R.A.; Barnhart, R.L.; Chen, K.S.; Edwards, M.L.; Matt, J.E.; Rhinehart, B.L.; Robinson, K.M.; Vaal, M.J.; Yates, M.T. Antioxidant and cholesterol lowering properties of 2,6-di-t-butyl-4-[(dimethylphenylsilyl)methyloxy] phenol and derivatives: a new class of anti-atherogenic compounds. Bioorganic \& Medicinal Chemistry Letters, 1996, 6, pp. 1559-1562.

16. Davidson, P.M.; Naidu, A.S. Phyto-phenol. In: Natural Food Antimicrobial Systems. Naidu, A.S. Eds. CRC Press: Boca Raton, FL, 2000, pp. 265-294.

17. Wrigglesworth, R.; Walpole, C.S.J.; Bevan, S.; Campbell, E.A.; Dray, A.; Hugues, G.A.; James, I.; Masdin, K.J.; Winter, J. Analogues of capsaicin with agonist activity as novel analgesic agents: structure-activity studies. 4. Potent, orally active analgesics. Journal of Medicinal Chemistry, 1996, 39, pp. 4942-4951.

18. Murata, S.; Sundell, C.L.; Lijkwan, M.A.; Balsam, L.B.; Hammainen, P.; Coleman, C.; York, C.; Luchoomun, J.; Suen, K.-L.; Howard, R.; Somers, P.K.; Morris, R.E.; Robbins, R.C. Effects of AGI-1096, a novel antioxidant compound with anti-inflammatory and antiproliferative properties, on rodent allograft arteriosclerosis. Transplantation, 2004, 77, pp. 1494-1500.

19. Jordan, V.C. Antiestrogens and selective estrogen receptor modulators as multifunctional medicines. 2. Clinical considerations and new agents. Journal of Medicinal Chemistry, 2003, 46, pp. 1081-1111.

20. Poirier, D. 17ß-Hydroxysteroid dehydrogenase inhibitors: a patent review. Expert Opinion on Therapeutic Patents, 2010, 20, pp. 1123-1145.

21. Poirier, D. Inhibitors of 17ß-hydroxysteroid dehydrogenases. Current Medicinal Chemistry, 2003, 10, pp. 453-477.

22. Marchais-Oberwinkler, S.; Henn, C.; Moller, G.; Klein, T.; Negri, M.; Oster, A.; Spadaro, A.; Werth, R.; Wetzel, M.; Xu, K.; Frotscher, M.; Hartmann, R.W.; Adamski, J. 17beta-Hydroxysteroid dehydrogenases (17beta-HSDs) as therapeutic targets: protein structures, functions, and recent progress in inhibitor development. The Journal of Steroid Biochemistry and Molecular Biology, 2011, 125, pp. 66-82.

23. Fournier, D.; Poirier, D. Chemical synthesis and evaluation of $17 \alpha$-alkylated derivatives of estradiol as inhibitors of steroid sulfatase. European Journal of Medicinal Chemistry, 2011, 46, pp. 4227-4237.

24. Boivin, R.P.; Luu-The, V.; Lachance, R.; Labrie, F.; Poirier, D. Structure-activity relationships of 17 $\alpha$-derivatives of estradiol as inhibitors of steroid sulfatase. Journal of Medicinal Chemistry, 2000, 43, pp. 4465-4478.

25. Ciobanu, L.C.; Maltais, R.; Poirier, D. The sulfamate functional group as a new anchor for solid-phase organic synthesis. Organic Letters, 2000, 2, pp. 445-448.

26. Okada, M.; Iwashita, S.; Koizumi, N. Efficient general method for sulfamoylation of a hydroxyl group. Tetrahedron Letters, 2000, 41, pp. 7047-7051.

27. Spillane, W.J.; Hogan, G.; McGrath, P.; King, J.; Brack, C.J. Aminolysis of sulfamate esters in non-aqueous solvents. Evidence consistent with a concerted E2-type mechanism. Journal of the Chemical Society, Perkin Transactions 2, 1996, 10, pp. 2099-2104.

28. Spillane, W.J.; McHugh, F.A.; Burke, P.O. Aminolysis of sulfamate esters in chloroform - nonlinear kinetics. Journal of the Chemical Society, Perkin Transactions 2, 1998, 2, pp. 309-313.

29. Spillane, W.J. Novel change in rate-determining step within an E1cB mechanism during aminolysis of a sulfamate ester in acetonitrile. Chemical Communications, 1998, 9, pp. 1017-1018.

30. Spillane, W.J.; McGrath, P.; Brack, O.; O’Byrne, A.B. Change in rate-determining step in an E1cB mechanism during aminolysis of sulfamate esters in acetonitrile. Journal of Organic Chemistry, 2001, 66, pp. 6313-6316.

31. Ciobanu, L.C.; Poirier, D. Solid-phase parallel synthesis of 17alpha-substituted estradiol sulfamate and phenol libraries using the multidetachablesulfamate linker. Journal of Combinatorial Chemistry, 2003, 5, pp. 429-440.

32. Ciobanu, L.C.; Poirier, D. Synthesis of libraries of $16 \beta$-aminopropyl estradiol derivatives for targeting two key steroidogenic enzymes. ChemMedChem, 2006, 1, pp. 1249-1259.

33. Bérubé, M.; Delagoutte, F.; Poirier, D. Preparation of libraries of $16 \beta$-estradiol derivatives as bisubstrate inhibitors of type $117 \beta$-hydroxysteroid dehydrogenase using the multidetachablesulfamate linker. Molecules, 2010, 15, pp. 1590-1631.

34. Peterson, E.M.; Brownell, J.; Vince, R. Synthesis and biological evaluation of 5'-sulfamoylated purinyl carbocyclic nucleosides. Journal of Medicinal Chemistry, 1992, 35, pp. 3991-4000. 